\title{
Acquired cystic renal disease in hemodialysis patients.
}

\author{
MBBS, FCPS (Medicine) \\ FCPS (Nephrology) \\ Assistant Professor Nephrology \\ QAMC/BVH, Bahawalpur. \\ 2. MBBS, FCPS (Medicine) \\ Senior Registrar Medicine \\ Quaid-e-Azam Medical College, \\ Bahawalpur. \\ 3. MBBS, FCPS (Nephrology) \\ Assistant Professor Nephrology \\ QAMC/BVH, Bahawalpur. \\ 4. MBBS \\ Registrar Radiology \\ QAMC/BVH, Bahawalpur. \\ 5. MBBS \\ PGR Nephrology \\ QAMC/BVH, Bahawalpur. \\ 6. MBBS \\ PGR Nephrology Unit \\ QAMC/BVH, Bahawalpur.
}

Correspondence Address:

Dr. Raheel Khan

Department of Nephrology

Quaid-e-Azam Medical College,

Bahawalpur.

x_raheel@yahoo.com

Article received on:

13/02/2020

Accepted for publication:

09/04/2020

\begin{abstract}
Suhail Iqbal Malik ${ }^{1}$, Raheel Khan², Muhammad Yousuf ${ }^{3}$, Muhammad Imran ${ }^{4}$, Yusra Saeed ${ }^{5}$, Muhammad Ahmad 6

ABSTRACT... Objectives: The objective of this study was to determine the frequency of Acquired cystic renal disease in patients on hemodialysis. Study Design: Cross Sectional study. Setting: Bahawal Victoria Hospital, Bahawalpur-Pakistan. Period: Jan 2019 to June 2019. Material \& Methods: Patients on maintenance hemodialysis were evaluated using ultrasound for acquired cystic renal disease. Results: The study included 220 patients who were on maintenance hemodialysis. The male to female ratio was 2.01:1. Most common causes of renal failure were Diabetes Mellitus and Renal stone Disease (22.3\%) each. Acquired cystic renal disease was found in 45 (20.5\%). The difference of frequency of acquired cystic renal disease was statistically significant in age groups \& anemia. Conclusions: Acquired cystic renal disease is common complication of End stage renal disease and maintenance hemodialysis. Regular monitoring with ultrasound needs to be done for those patients who are on maintenance hemodialysis for more than 3 years.
\end{abstract}

Key words: $\quad$ Acquired Cystic Renal Disease, Chronic Kidney Disease, Hemodialysis.

Article Citation: Malik SI, Khan R, Yousuf M, Imran M, Saeed Y, Ahmad M. Acquired cystic renal disease in hemodialysis patients. Professional Med J 2020; 27(11):2403-2406. https://doi.org/10.29309/TPMJ/2020.27.11.4568

\section{INTRODUCTION}

Renal replacement therapy (hemodialysis, peritoneal dialysis, renal transplantation) is now opted by huge number of patients suffering from end stage renal disease. It not only imposes economic but also social burden on country wide health plans. ${ }^{1}$ different complications of end stage renal disease include anemia, hypertension, fluid over load, bone mineral disease, acidosis are commonly seen in practice but Acquired cystic renal disease is also known complication. In this entity, patient develops numerous fluid filled cysts in the kidney while having no prior history or diagnosis of hereditary cystic disease of kidney. ${ }^{1}$

It is necessary to distinguish from adult polycystic kidney disease from Acquired cystic renal disease. In Acquired cystic renal disease there is no family history and there is no cyst formation in other organs of body as in APKD and their size ranges from normal to small in size which is contrary to APKD. ${ }^{2-4}$
The symptoms of Acquired cystic renal disease range from being asymptomatic to having hematuria, lumbar pain and recurrent urinary tract infections. These cysts are also associated with development of renal cell carcinoma with distant metastasis. ${ }^{5,6}$ Therefore it is necessary to make its early diagnosis.

\section{OBJECTIVE}

The objective of this study was to determine the frequency of Acquired cystic renal disease in patients on hemodialysis at Bahawal Victoria Hospital, Bahawalpur, Pakistan.

\section{MATERIAL \& METHODS}

This cross-sectional study was conducted from Jan 2019 to June 2019 at Dialysis Unit, Bahawal Victoria Hospital, Bahawalpur. Patients of age more than 18 years of either gender were included in the study. Patients having APKD, Medullary cystic disease of kidney and who refused to give consent were excluded from the study. 
Data was collected with pre-designed pre-tested questionnaire. Renal Ultrasonography was performed by same radiologist.

SPSS v.23.0 was used to analyze data. Frequencies and percentages were calculated for qualitative variables. Mean and standard deviation were calculated for quantitative variables. Effect modifiers were controlled through stratification. Post stratification chi-square test was applied by taking $\mathrm{p}=<0.05$.

\section{RESULTS}

Out of 260 patients registered for maintenance hemodialysis 220 were included in the study. 25 patients had APKD and 15 refused to give consent.

There were 147 (66.8\%) male and 73 (33.2\%) female with male to female ratio 2.01:1. 17(7.7\%) had history of smoking. The most common causes of renal failure were Diabetes Mellitus
(22.3\%) \& Renal stone disease (22.3\%) (Figure-1). Acquired cystic disease was found in 45 (20.5\%) (Figure-2). 9 (4.1\%) were HBsAg reactive and 110 (50\%) were anti-HCV reactive patients (Figure-3). Most of patients belonged to age group 26-50 years $118(53.6 \%)$ \& duration of hemodialysis for one to two years 84 (38.2\%). Anemia was present in 105 (47.7\%) and low serum albumin was present in $49(22.3 \%)$.

The difference of frequency of acquired cystic disease was statistically significant in age groups \& anemia (Table-I \& II). No statistical significance was found in gender, history of smoking, cause of renal failure, HBsAg, anti-HCV, duration of hemodialysis and low serum albumin.

Mean age of patients were $42.16 \pm 14.921$, duration of dialysis was $27.39 \pm 25.6$ months, hemoglobin was $10.127 \pm 2.26 \mathrm{~g} / \mathrm{dl}$ and serum albumin was $4.69 \pm 11.89$ (Table-III).

\begin{tabular}{|c|c|c|c|c|c|c|}
\hline & & \multicolumn{3}{|c|}{ Age Groups } & \multirow[b]{2}{*}{ Total } & \multirow[b]{2}{*}{ P-Value } \\
\hline & & $\begin{array}{c}\text { Less than } 26 \\
\text { years }\end{array}$ & $26-50$ years & $\begin{array}{c}\text { More than } 50 \\
\text { years }\end{array}$ & & \\
\hline \multirow{2}{*}{ Acquired cystic renal disease } & No & 35 & 93 & 47 & 175 & \multirow[b]{2}{*}{0.008} \\
\hline & Yes & 1 & 25 & 19 & 45 & \\
\hline
\end{tabular}

Table-I. Frequency of acquired cystic renal disease in different age groups

\begin{tabular}{|l|l|c|c|c|c|}
\hline \multicolumn{2}{|c|}{} & \multicolumn{2}{|c|}{ Anemia } & Total & P-Value \\
\cline { 2 - 5 } & & Yes & No & 175 \\
\hline \multirow{2}{*}{ Acquired cystic renal disease } & No & 90 & 85 & 45 \\
\cline { 2 - 6 } & Yes & 15 & 30 & 220 \\
\hline \multirow{2}{*}{ Total } & & 105 & 115 & 0.03 \\
\hline
\end{tabular}

Table-II. Frequency of acquired cystic renal disease in anemia

\begin{tabular}{|l|c|c|c|c|}
\hline & $\begin{array}{c}\text { Age } \\
\text { (in years) }\end{array}$ & $\begin{array}{c}\text { Duration of Hemodialysis } \\
\text { (in months) }\end{array}$ & $\begin{array}{c}\text { Hemoglobin } \\
\text { (g/dl) }\end{array}$ & $\begin{array}{c}\text { Serum Albumin } \\
\text { (g/d) }\end{array}$ \\
\hline Mean & 42.16 & 27.39 & 10.127 & 4.696 \\
\hline Std. Deviation & 14.921 & 25.600 & 2.2652 & 11.8997 \\
\hline
\end{tabular}

Table-III. Mean and standard deviation of quantitative variables 


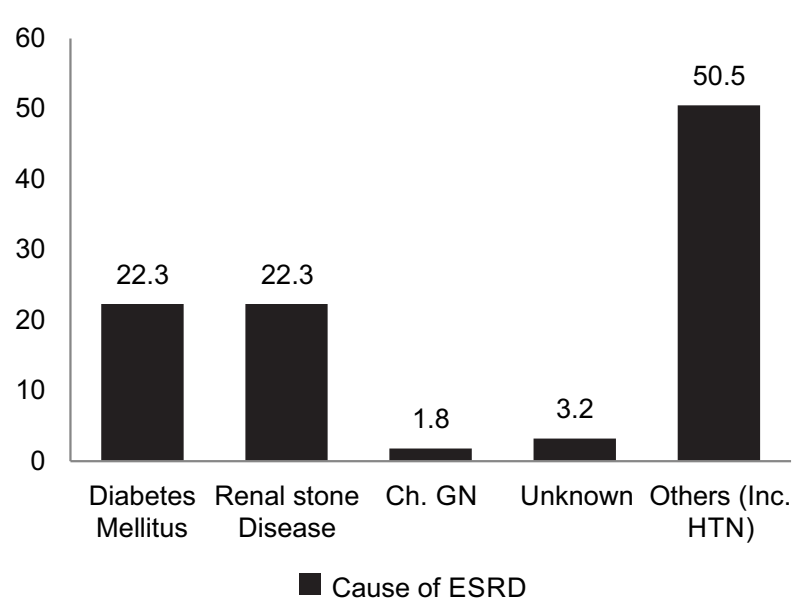

Figure-1. Cause of renal failure (in percentages)

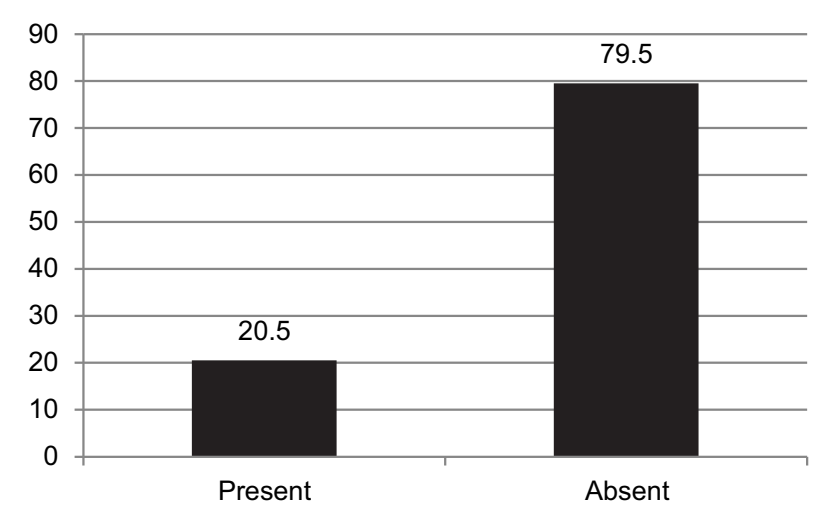

Figure-2. Acquired cystic renal disease

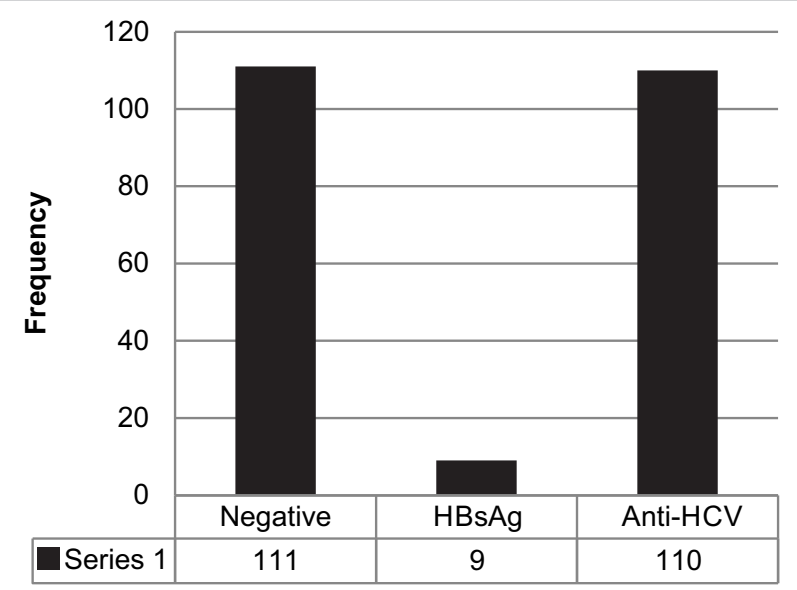

Figure-3. Viral marker status of patients

\section{DISCUSSION}

Acquire cystic renal disease was first described by Dunhill and co-worker while doing autopsy on patients who had end stage renal disease. ${ }^{7}$ After that many studies have been performed to know its prevalence, pattern and complications. ${ }^{8-10}$
In this study its prevalence was $20.5 \%$ which is similar to different studies conducted in different parts of world. For example studies conducted in West Africa, Jordan and Pakistan had frequency of Acquired cystic renal disease in hemodialysis patients as $31 \%, 22 \%, 10 \%{ }^{11,12}$ However different studies used different diagnostic approaches like CT scan, Histopathology of nephrectomy samples and autopsy of patients after their death. However these diagnostic tools cannot be used as screening method for Acquired cystic renal disease in patients.

In different studies acquire cystic disease of kidney has more prevalence in males than in females. This can be explained by effect of testosterone on increasing tubular hyperplasia and cyst formation. ${ }^{11,13}$ In this study there was no statistical difference in prevalence of this condition among males and females. A cohort study done by Gnionsahe also revealed the same results. ${ }^{10}$

The prevalence of Acquired cystic renal disease increase with increase in duration of hemodialysis as demonstrated in different studies. Patients having duration of hemodialysis for more than 3 years had increased prevalence of this condition than others. ${ }^{13,14}$ These studies suggest that duration of hemodialysis and kidney failure can be risk factors for this condition in adults and children. ${ }^{15}$ However there was no statistical significance was noted in this study.

No statistical significance was seen regarding the prevalence of this condition and cause of renal failure in the patients. Similar observations were also showed by other authors regarding this subject. ${ }^{11,16}$

\section{CONCLUSION}

Regardless of etiology of end stage renal disease, Acquired cystic renal disease is common complication of hemodialysis and its prevalence increases with duration of hemodialysis. Having risk of renal cell carcinoma this condition needs to be looked for regularly by ultrasound in patient who are having hemodialysis for more than 3 years.

Copyright $\odot 09$ Apr, 2020. 


\section{REFERENCES}

1. The United States Renal Data System. Excerpts from the USRDS 2008 annual data report: Atlas of endstage renal disease in the United States. Am J Kidney Dis. 2009; 1(Suppl 1):S111-296.

2. Harris PC, Torres VE. Autosomal dominant polycystic kidney disease. Gene Reviews [cited 9 April 2010]. Available from: http://www.ncbi.nlm.nih.gov/bookshelf/ br.fcgi?book=gene\&part=pkd-ad.

3. Grantham JJ. Clinical practice. Autosomal dominant polycystic kidney disease. N Engl J Med. 2008; 359: 1477-85.

4. Torres VE, Harris PC, Pirson Y. Autosomal dominant polycystic kidney disease. Lancet. 2007;369:1287-301.

5. Truong LD, Krishnan B, Cao JT, Barrios R, Suki WN. Renal neoplasm in acquired cystic kidney disease. Am J Kidney Dis. 1995; 26:1-12.

6. Levine E, Slusher SL, Grantham JJ, Wetzel LH. Natural history of acquired renal cystic disease in dialysis patients: A prospective longitudinal CT study. AJR Am J Roentgenol. 1991; 156:501-6.

7. Dunnill MS, Millard PR, Oliver D. Acquired cystic disease of the kidneys: A hazard of long-term intermittent maintenance haemodialysis. $\mathrm{J}$ Clin Pathol. 1977; 30: 868-77.

8. Liu JS, Ishikawa I, Horiguchi T. Incidence of acquired renal cysts in biopsy specimens. Nephron. 2000; 84:142-7.
9. Ishikawa I, Saito Y, Shikura N, Kitada H, Shinoda A, Suzuki $S$. Ten-year prospective study on the development of renal cell carcinoma in dialysis patients. Am J Kidney Dis. 1990; 16:452-8.

10. Gnionsahe DA, Lagou DA, Tia WM. Prevalence of acquired cystic disease in black Africans on hemodialysis in West Africa. Saudi J Kidney Dis Transpl. 2007; 18:114-6.

11. Ishikawa I. Acquired cystic disease: Mechanisms and manifestations. Semin Nephrol. 1991; 11:671-84.

12. Matson MA, Cohen EP. Acquired cystic kidney disease: Occurrence, prevalence, and renal cancers. Medicine (Baltimore). 1990; 69:217-26.

13. Narasimhan N, Golper TA, Wolfson M, Rahatzad M, Bennett WM. Clinical characteristics and diagnostic considerations in acquired renal cystic disease. Kidney Int. 1986; 30:748-52.

14. [No authorlisted]. Acquired cystic kidney disease in children undergoing continuous ambulatory peritoneal dialysis. Kyushu Pediatric Nephrology Study Group. Am J Kidney Dis. 1999; 34:242-6.

15. Chan E, Warady B. Acquired cystic kidney disease: An under-recognized condition in children with end-stage renal disease. Pediatric Nephrology. 2017; 33(1):41-51.

16. Grantham JJ. Acquired cystic kidney disease. Kidney Int. 1991; 40:143-52.

\begin{tabular}{|c|c|c|c|}
\hline \multicolumn{4}{|c|}{ AUTHORSHIP AND CONTRIBUTION DECLARATION } \\
\hline Sr. \# & Author(s) Full Name & Contribution to the paper & Author(s) Signature \\
\hline 1 & Suhail Iqbal Malik & $\begin{array}{l}\text { Conception \& design, acquisition of } \\
\text { data, analysis \& interpretation of data, } \\
\text { Drafting the article, Revising it critically for } \\
\text { important intellectual content. }\end{array}$ & \\
\hline 2 & Raheel Khan & $\begin{array}{l}\text { Conception \& design, acquisition of data, } \\
\text { analysis \& interpretation of data, Drafting }\end{array}$ & \\
\hline 3 & Muhammad Yousuf & $\begin{array}{l}\text { the article. } \\
\text { Drafting the article, Revising it critically for } \\
\text { important intellectual content. }\end{array}$ & \\
\hline 4 & Muhammad Imran & $\begin{array}{l}\text { Drafting the article, Revising it critically for } \\
\text { important intellectual content. }\end{array}$ & \\
\hline 5 & Yusra Saeed & $\begin{array}{l}\text { Conception \& design, acquisition of data, } \\
\text { analysis \& interpretation of data, Drafting } \\
\text { the article. }\end{array}$ & \\
\hline 6 & Muhammad Ahmad & $\begin{array}{l}\text { Conception \& design, acquisition of data, } \\
\text { analysis \& interpretation of data, Drafting } \\
\text { the article. }\end{array}$ & \\
\hline
\end{tabular}

